\title{
The Impact of Financial Crisis on B2C e-Commerce
}

\author{
Fateme Ghadami, Abdollah Aghaie, Morteza Mohammadkhan
}

IT Group-Faculty of Industrial Engineering, K. N. Toosi University of Technology, Tehran, Iran.

Email: Fateme.ghadami@gmail.com, aaghaie@kntu.ac.ir,m.m.khan@kntu.ac.ir

Received October $13^{\text {th }}$, 2009; revised February $1^{\text {st }}, 2010$; accepted March $6^{\text {th }}, 2010$.

\begin{abstract}
Many experts believe that the global financial crisis in 2008 is the worst of its kind since the Great Depression in 1929. The crisis was started from housing market in the US and spread quickly into financial markets. It has had a ripple effect around the world and many other industrialized economies were troubled by its consequences and almost every industry has been influenced by its outcomes. Online retail (or B2C e-Commerce) as a part of retail industry was not immune from the financial crisis and its sales has a dramatic decline. In this paper it is found that 3 factors are main players which have impacted on online retail sales including: less credit available; increasing saving rate and decreasing consumption expenditures and falling consumer confidence and sentiment. Also by representing several figures and tables, factors affecting this trend such as age class, income and gender are discussed.
\end{abstract}

Keywords: Financial Crisis, Online Retail, B2C e-Commerce

\section{Introduction}

The year of 2008 was not a good year for economy. In this year many countries were troubling by financial crisis. Many experts believe the crisis was started from housing market in the US and then was spread into financial markets. Through this way many banks and financial firms around the globe were affected by consequences of the crisis.

The housing bubble in the United States grew up alongside the stock bubble in the mid-90s. Increasing in stock prices made unexpected wealth for people and they started to spend this extra money. This led to the consumption boom of the late $90 \mathrm{~s}$, with saving rate out of disposable income falling from close to $5 \%$ in the middle of the decade to just over $2 \%$ by 2000 [1]. This extra money encourages people to buy better and bigger homes. So it results in exceeding demand than supply because in the short-run the supply of housing is relatively fixed. This increase in demand triggered housing bubble and it led to an increase in price. Therefore the house price grew from 1992 to 2005 and it peaked in 2006. After that by bursting the housing bubble, prices started to decline.

The signs of financial crisis appear by housing bubble burst and drastic decline in house prices which were started in 2007, and eventually with the failure, merger or conservatorship of several large United State-based financial firms it became prominently visible in September
2008. The crisis had a ripple effect around the world and many other industrialized economies were troubled by its consequences. It caused a deep recession and many believe the crisis is the worst of its kind since the Great Depression in 1929.

Outcomes of the crisis are not just limited to financial and housing markets. Its consequences have spread around the world and affected almost all aspects of people's lives. For example it has several significant socioeconomic impacts such as:

Increasing unemployment rate: By incidence the financial crisis, companies tried to reduce their expenses so as a solution they cut the number of their employees. Therefore the crisis resulted in increasing in unemployment rate.

Inflation or deflation: The crisis has had both inflationary and deflationary effects in the world. It causes people have less credit to finance their purchases so by diminishing trades and decrease in demand, prices come down. This situation is named deflation. On the other hand to repel the crisis some governments injects money into society. Sometimes this decision has inflationary results as it caused increasing inflation rate in some countries [2].

Moreover, the financial crisis has influenced major industries such as auto manufacturers, health insurance, tourism and etc. Another major industry which is influenced by the financial crisis is retail industry. Retail in- 
dustry composed of 2 main sections: offline or traditional retail and online retail (business to consumer or simply B2C). In another point of view online retail is a kind of e-Commerce which can be categorized under the IT industry. This paper is trying to investigate how the global financial crisis in 2008 has affected online retail.

\section{Background}

Since the global financial crisis is a recent event, there is no particular academic research about its probable effects on e-Commerce, specially B2C e-Commerce or online retail. There are just a few news websites or market research websites which have performed researches related to this topic. For example NYTIMES.com and Forrester Research Inc. are two main websites which had some information about the impact of financial crisis on e-Commerce. According to [3] it was predicted the financial crisis would not have any visible impact on technology sector. It was expected jus Internet advertisement companies that got much of their business from mortgage brokers and some software companies which sell their product to financial services companies would face trouble. But after a while on October 2008 Wall Street Journal notified that the technology industry which had seemed immune to the financial crisis, was squeezed because of slackening demand and cutting costs to prepare for a prolonged downturn [4]. Companies like Intel in hardware sector and SAP in software sector have faced such problems. Also, to reduce costs some other giant companies like Google, Yahoo and eBay have cut down the number of their employees. Altogether, it can be said the technology sector like other industries is affected by the consequences of the financial crisis. Actually the crisis has affected customer behavior in many ways. It has changed customers' buying priority.

\section{Statistics and Analysis}

Occurrence of financial crisis has a significant impact on the US economy. Increasing unemployment rate and lack of a strong financial resource for household have caused their buying power has diminished and people are forced to have a fundamental revision on their shopping way.

By comparing statistics from [5-10], it can be clearly seen that online retail is affected by the crisis (Table 1).
In the first quarter of 2008 and before appearing crisis signs, online retail sales was about \$ 32.4 billion, a growth of $13.4 \%$ respect to the same period time last year. $16.9 \%$ decline in online retail sales in the first quarter of 2008 respect to prior quarter was because of increasing sales in the holiday season as there is in the $4^{\text {th }}$ quarter of 2008 and $1^{\text {st }}$ quarter of 2009. In the 2 next quarters it has $8.9 \%$ and $4.6 \%$ growth respect to same period in the last year, a decreasing growth. Totally can be seen in 2008 online retail has a decreasing growth and in 2009 it reached to an increasing negative growth. These statistics show how the financial crisis has affected online retail industry. It has caused a decline in overall growth rate for the industry. There could be supposed several reasons for the decline:

Online buyers have less available credit to finance their purchases [11]. A consequence of financial crisis is Credit Crisis. A credit crisis is a reduction in the general availability of loans or a sudden tightening of the conditions required to obtain a loan from the banks [12]. So consumers are no longer to take equity out of their homes to fund spending. Moreover less credit available causes fewer credit cards issues. One important feature which attract consumer to buy online is convenient use of credit cards. Credit crisis has an effect on online buyers spending through credit cards.

Economic conditions have forced people to save more than past [11]. According to [13] in the past 4 quarters consumption expenditures had negative growth, in third and fourth quarters of 2008 it had $4.7 \%$ and 5\% decline respectively and in the first and second quarters of 2009 with smoother decline it had $1.5 \%$ and $1.3 \%$ negative growth respectively. Moreover saving rate has had a significant growth rate in the same period (Table 2). It reached from $2.2 \%$ in third quarter of 2008 to $5 \%$ in second quarter of 2009.

Reduced consumption expenditures means decline in spending by customer and increasing saving rate also implies further decline. In these economic conditions people try to do something which makes them feel more confident. With less job security and increasing unemployment rate they try to reserve a safe financial source for hard times. This situation can be translated into difficult times for retail industry. In a recession period online buyers look for retailers who discount their products and

Table 1. Retail and online retail sales 2008 - 2009 [5-10]

\begin{tabular}{|c|c|c|c|c|c|}
\hline & $\begin{array}{l}\text { Online Retail } \\
\text { Sales }\end{array}$ & $\begin{array}{l}\text { Percent Change From } \\
\text { Prior Quarter }\end{array}$ & $\begin{array}{l}\text { Online retail sales Percent Change } \\
\text { From Same Quarter a Year Ago }\end{array}$ & $\begin{array}{c}\text { retail sales Percent Change From } \\
\text { Same Quarter a Year Ago }\end{array}$ & $\begin{array}{l}\text { Online retail as a } \\
\text { Percent of Total }\end{array}$ \\
\hline $1^{\text {st }}$ Q 2008 & $\$ 32.4$ billion & $-16.9 \%$ & $13.4 \%$ & $3.7 \%$ & $3.4 \%$ \\
\hline $2^{\text {nd }}$ Q 2008 & $\$ 32.5$ billion & $0.5 \%$ & $8.9 \%$ & $2.3 \%$ & $3.1 \%$ \\
\hline $3^{\text {rd }}$ Q 2008 & $\$ 31.6$ billion & $-2.8 \%$ & $4.6 \%$ & $0.9 \%$ & $3.1 \%$ \\
\hline $4^{\text {th }} \mathrm{Q} 2008$ & $\$ 37.1$ billion & $17.3 \%$ & $-5.5 \%$ & $-8.6 \%$ & $3.8 \%$ \\
\hline $1^{\text {st }}$ Q 2009 & $\$ 30.2$ billion & $-17.7 \%$ & $-5.7 \%$ & $-11.6 \%$ & $3.6 \%$ \\
\hline $2^{\text {nd }}$ Q 2009 & $\$ 30.8$ billion & $2.1 \%$ & $-4.5 \%$ & $-10.6 \%$ & $3.3 \%$ \\
\hline
\end{tabular}


Table 2. Consumption expenditures and saving rate 2008 - 2009 [13]

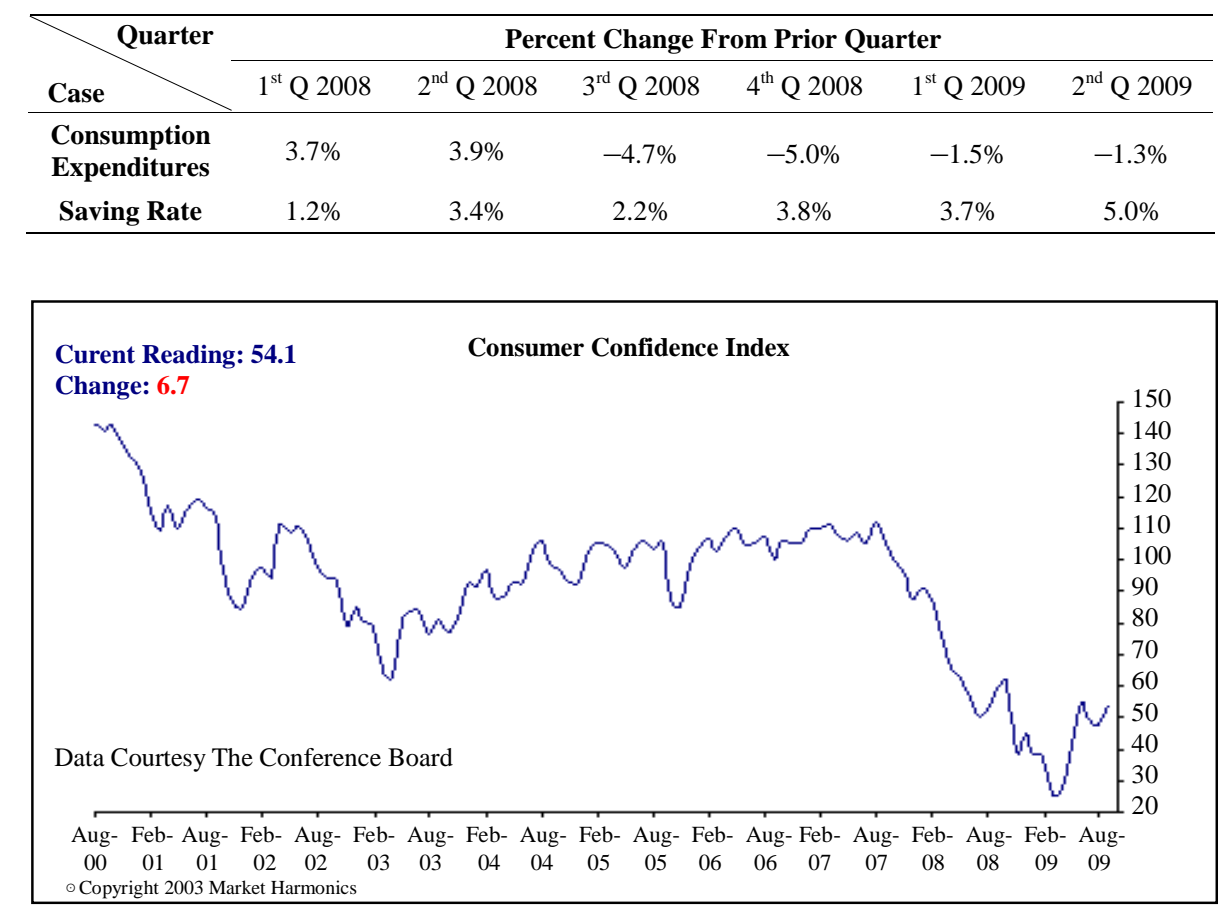

Figure 1. Consumer confidence index (CCI) 2000 - 2009

services. Those retailers who sell luxury brands and specialty products will damage more than others.

Other effecting factors are CCI and CSI indices. These factors measure consumers' attitude toward economy and their own financial conditions and are indicators designed to measure consumer confidence, which is defined as the degree of optimism on the state of the economy that consumers are expressing through their activities of saving and spending [12] Based on Figure 1 CCI has sharply declined through August 2007 to February 2009. It means people became more pessimists about the economy. Also CSI which is represented by Reuters/University of Michigan Surveys of consumers has a similar trend. According to the August report Consumers increasingly expect the economy to improve in the months ahead even as they report the worst assessments of their personal finances since the surveys began in 1946. Although the economic recovery is likely to have already started, consumers' spending will remain in low gear for an extended period of time. Director of the survey has said the growth of total personal consumption expenditures at just $1.6 \%$ during 2010. The Index of Consumer Sentiment was 65.7 in the August 2009 survey, just below the 66.0 in July and the 67.5 in last year's August survey. The key August change was in the job situation. Consumers believed the unemployment rate was nearing its cyclical peak, although most thought it would still increase to just above $10 \%$ [14].

\section{Traditional Retail vs. Online Retail}

Aforementioned reasons have caused online retail sales to decline, though by referring to Table $\mathbf{1}$ and comparing total retail and online retail, it can be inferred that traditional retail had a bigger reduction in sales than online retail. Several reasons could be supposed for this situation:

Online retail has attractive inherent features which are inherited from electronic commerce. Online consumers could easily buy everything they need ay any times in any where they have connection to Internet. So availability is an appealing characteristic of online retail (Figure 2).

Online shopping seems a less expensive way of buying. Searching products online make online buyers avoid impulse buying. Moreover they could use free shipping offers so it save money even more. Also usually there are many discount and bonus which are offered by retailer websites. Moreover pure online retailers don't have costs such as store maintenance, tax and etc so they could provide cheaper products or services. Also by shopping online, customers don't pay for fuel or transportation expenses.

Online buyers are typically wealthier and less affected by the economy. Online buyers with household incomes of $\$ 75,000$ or more, represent the largest group of the online buying population [11]. So recession does not affect this group severely and they won't change their shopping habits intensely. 
Disproportionate online spending by men will support online sales. The male/female spending split is almost equal online; this contrasts with offline, where women are commonly held to account for roughly $70 \%$ of purchases. The percentage of males who will shop less overall is 18 percentage points lower than the percentage of females who will adopt the same attitude as a result of the current state of the US economy [11].

Internet provides a comprehensive set of information related to a particular product or service. This facility attracts more people to shop online. They could conveniently use search engines to acquire information they need. Since online buying has no switching cost, online customer could freely use search engine to find what they want. Internet helps online buyers feel more confident that they are buying the right product to meet their needs.

Online shopping offers consumer and expert opinions [11]. Product reviews are one of the features that clearly distinguish the online experience from the offline one. This type of content offers an extra boost of confidence and will continue to attract consumers.

\section{Studying New Trends among Online Buyers after Financial Crisis}

Financial crisis of 2008 has changed online buyers' shopping habits. Actually they are trying to adapt themselves to new conditions. This adaptation has caused some new special trends among buyers and consequently online buyers.

New economic conditions have forced online buyers to cut back considerably on their online purchases. Many online consumers scaled down in holiday season of 2008. Holiday season usually is a good time for online retail industry but according to the results of surveys 70.8 percent of online consumers have said they are planning to spend less money holiday 2008 compared to past holiday seasons [15]. The online Holiday Spending Survey was conducted during the height of the worst economic crisis in decades which has had a significant impact on consumer confidence-a key driver in the consumer spending equation (Figure 3).

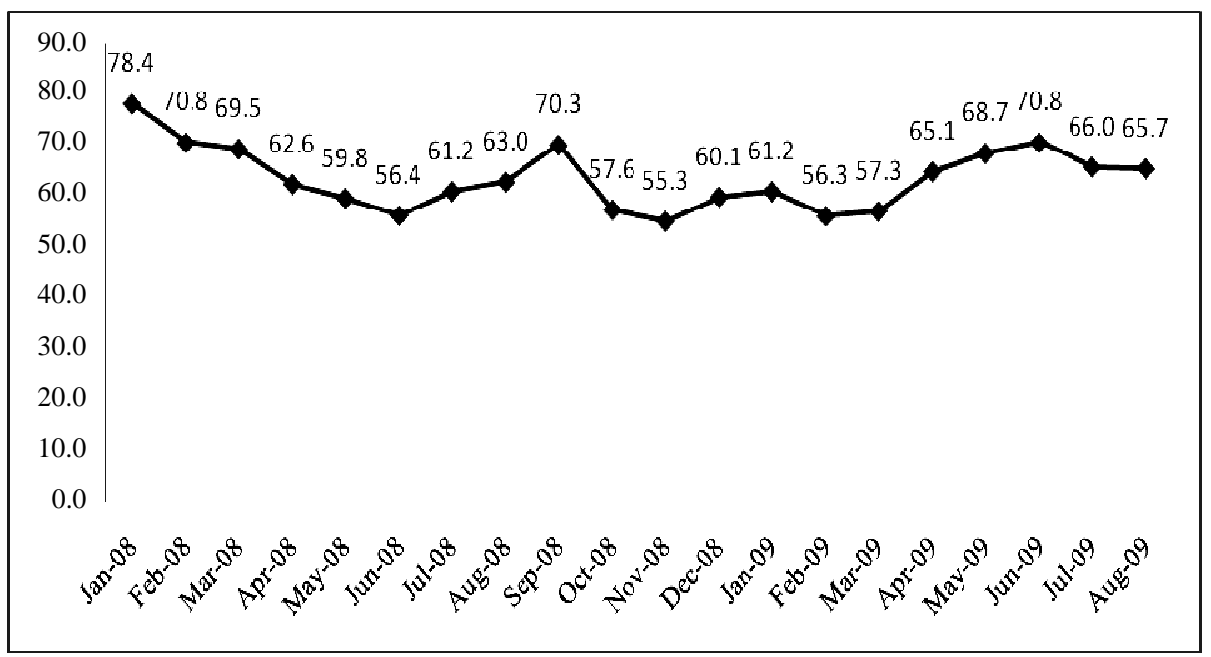

Figure 2. Consumer sentiment index (CSI) 2008 - 2009

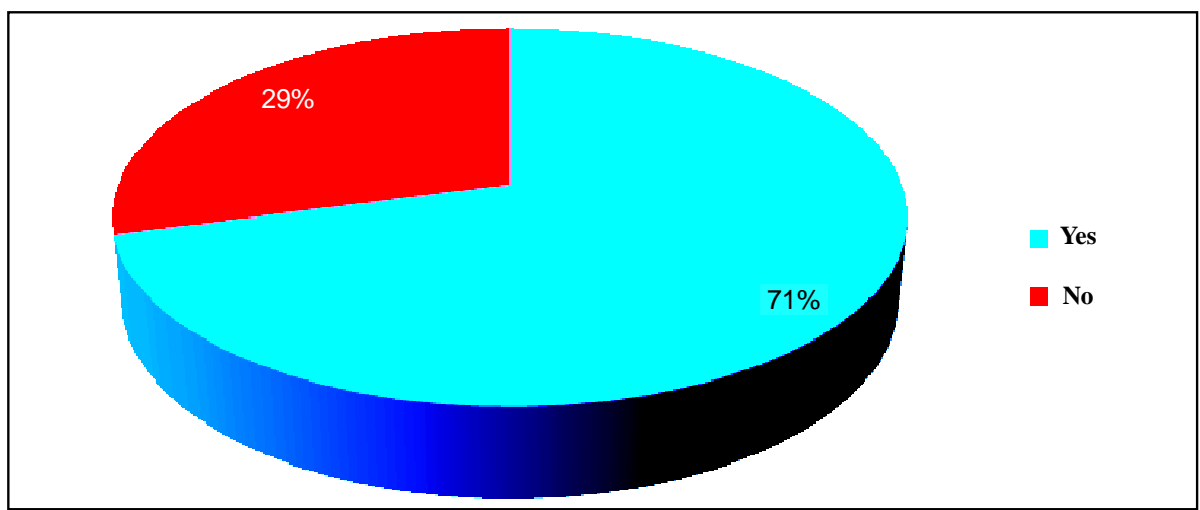

Figure 3. Are you planning to spend less money this holiday season than in past holiday seasons [15]? 
The factors that directly affect 70.8 percent of online consumer's decisions to spend less 2008 holiday season are: increasing prices of necessities (39.5\%), lack of confidence in the economy (30.6\%), less money coming in overall (14.1\%), and decreasing home values and other savings (Figure 4) [15].

Other significant contributing factors found in this survey (unemployment, lack of annual bonus, and credit line reduction) are closely tied to the effect the economy has on consumer's discretionary income.

When it comes to researching and purchasing 2008 holiday season, online shopping resources are gaining ground on the traditional offline approach. 96.5 percent of shoppers expected to do some purchasing online in 2008 holiday season. Survey results from the October 2007 Holiday Trends Survey compared to the recent Holiday
Spending Survey highlights that online consumers expected to purchase more online than last year. This holiday season, 55 percent of survey respondents expected to purchase more than half of their holiday gifts online, while only 45 percent had expected to purchase online last holiday season-an increase of 10 percentage points over a one year period (Figure 5) [15].

Holiday season of 2008 it was all about researching the lowest price and finding the best value. Convenience is secondary for most consumers. Online shoppers find shopping and purchasing online appealing because it is easier to compare and find the lowest price (37.4\%), it provides the convenience of shopping at anytime and from anywhere $(24.1 \%)$, it offers free shipping and return policies (23.9\%) and it provides online shopper to avoid stressful crowds and parking (14.6\%) (Table 3) [15].

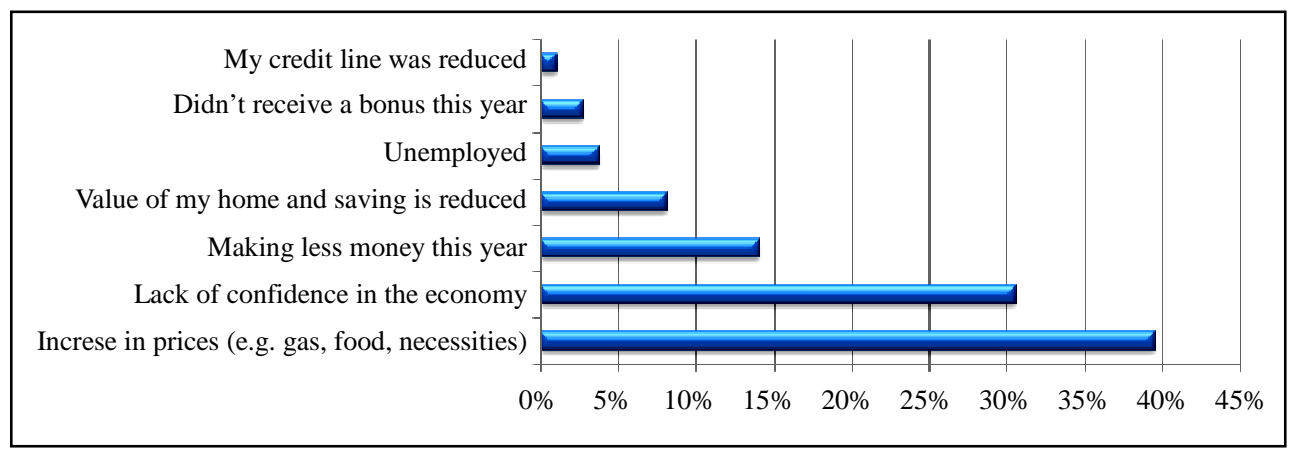

Figure 4. Why have you decided to spend less money holiday season of 2008? [15]

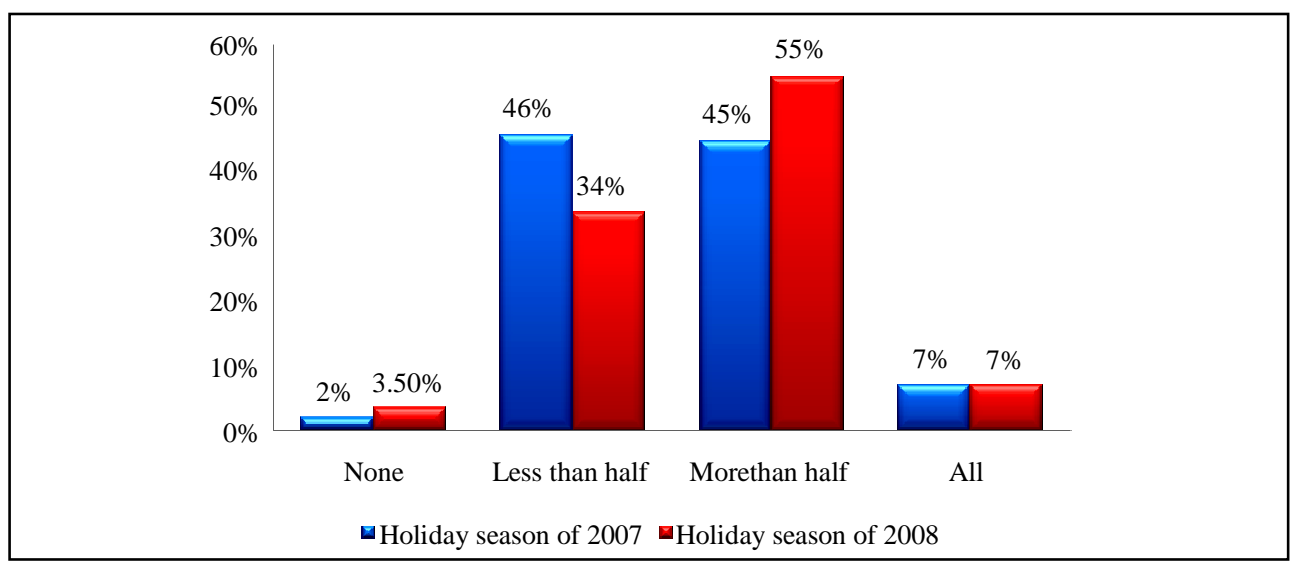

Figure 5. How much of your holiday purchasing do you expect to do ONLINE? [15]

Table 3. Which appeals to you most about shopping and purchasing ONLINE holiday season of 2008? [15]

\begin{tabular}{clc}
\hline Rank & \multicolumn{1}{c}{ Reason } & Percent \\
\hline 1 & Easier to compare and find the lowest price & 37.4 \\
2 & Convenience of shopping anytime/anywhere & 24.1 \\
3 & Free shipping offers and return policies & 23.9 \\
4 & Avoid stressful crowds and parking & 14.6 \\
\hline
\end{tabular}


Savvy online consumers have used a variety of techniques to save money in 2008 holiday season. The primary technique which 53.1 percent of online shoppers used this holiday season to save money was sticking to a budget to control impulse buying. Survey findings show that consumers were taking the time to research and find deals by shopping at discount or outlet stores (43.1\%), using shopping comparison Web sites (37.6\%), and only purchasing sale items (34.6\%) (Table 4) [15].

Online consumers struggling in a weak economy continue to use the Internet to shop. 91 percent of online shopper use Internet because researching products online makes them feels more confident about their purchases. Same percent of online buyers announce that comparing prices online reassures them that they are getting the best deal. Seventy-five percent of online consumers looked to purchase from merchants that do not charge sales tax or offer free-shipping. 54 percent of online buyer said they search for coupons and discounts online even if they plan to shop offline. Another 37 percent of online consumers used the Internet to purchase products because it helped them avoid impulse purchases (Figure 6) [16].

Women 'spend less' consistently more than men 'spend less'. Interestingly, a higher percentage of women reported that they made an effort to spend less on dining out $(74 \%)$, entertainment (72\%), and purchasing online (55\%) or purchasing in-store (69\%) as compared to men. Overall, the majority of consumers have spent less on eating out at restaurants (69\%), engaging in entertainment outside the home (67\%), purchasing consumer goods and services online (47\%) and in-store (63\%) in response to the tough economic times (Figure 7) [17].

Table 4. Which money saving techniques will you use in the next few months to save money on holiday shopping? [15]

\begin{tabular}{lc}
\hline \multicolumn{1}{c}{ Method } & Percent \\
\hline Stick to a budget to control impulse buying & 53.1 \\
Shop at discount or outlet stores & 43.1 \\
Use shopping comparison web sites & 37.6 \\
Only purchase sale items & 34.6 \\
Use a low interest credit card and/or cash & 15.5 \\
Not giving gifts to people who received them last year (e.g. co-workers, service attendants) & 10.1 \\
Make items (i.e. crafts) & 9.5 \\
\hline
\end{tabular}

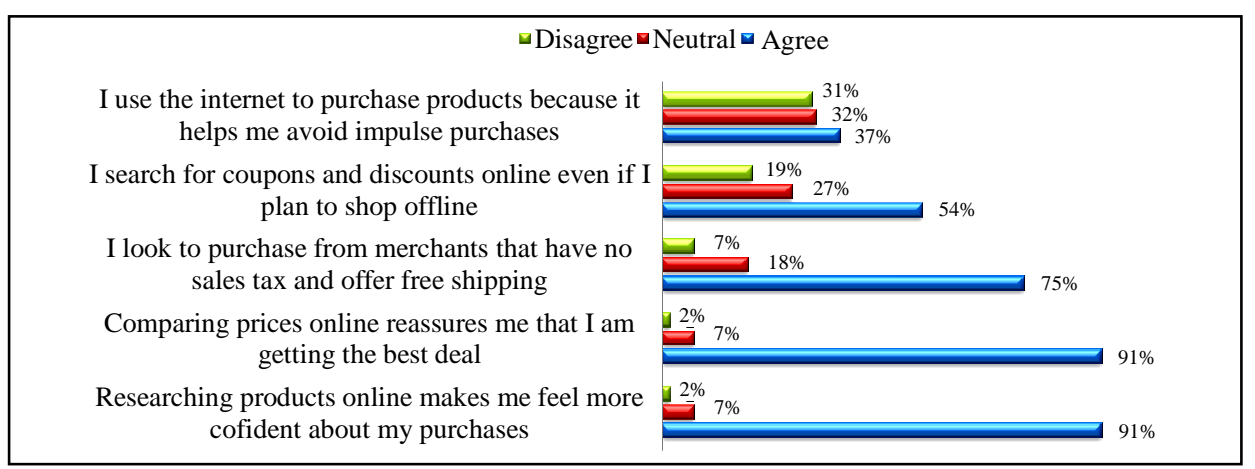

Figure 6. How much do you agree with the following statements about your spending behavior in this tough economy? [16]

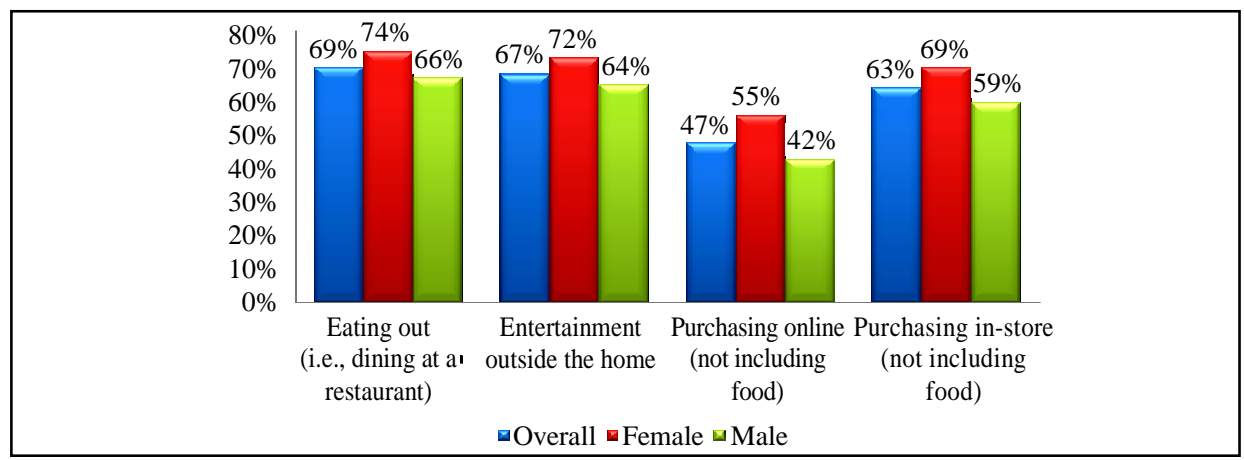

Figure 7. In the past 3 months, how has the current state of the U.S. economy impacted your money-spending on the folloing: "I spent less" [17] 
Another factor which affects online buyers' behaviors is their age class. According to the surveys people between 29 and 42 are most likely to delay making nonessential retail purchases in Q4 to conserve finances. These people were also the most likely to agree that they had tried to control fixed monthly costs such as utilities and that they had trimmed back on vacation plans. On the other hand older buyers-people older than 42-were more optimist and they expected the economy to get better in 2009. And when asked about specific changes they had made in spending in the Q4, they indicated that they took a practical approach to watching their budget: They were more likely to cut back on fixed monthly costs and conserve gas but were less likely to postpone travel [18].

Consumer spending varies within different income segments. Online buyers are wealthier and less affected by the economy. Online buyers with household incomes of $\$ 75,000$ or more represent the largest group of the online buying population. They make up more than $40 \%$ of all online buyers - almost twice the number of those with household incomes of $\$ 50,000$ to $\$ 75,000$. They are also less affected by the economy than the average consumer. This group makes an average of 10 purchases per year, which is two more than the average online buyer. Survey findings demonstrate that 37.7 percent of consumers making more than $\$ 100,000$ say they do not plan to spend less this holiday season. Of these consumers, 38.9\% indicated "I don't feel the effects of the economy." Whereas 22.4 percent of consumers making less than \$50,000 say they do not plan to spend less this holiday season compared to past holiday seasons (Figure 8) [11].

\section{Analysis}

According to the statistics described above, it is obvi- ously seen that online retail has encountered a big challenge during 2008 and still is straining to conquest it. Recession, increasing unemployment rate and reduced consumers confidence are factors that play roles in growing the challenge. Although e-commerce has attractive features but it was not immune from the crisis. As can be seen in Table $\mathbf{1}$ like other industries, retail industry has been faced problem and its sales declined dramatically. In spite of these problems people still have preferred online retail and it has a greater portion of their shopping as compared with past year. There could suppose several reasons for this trend. Online shopping seems as a less expensive way to purchase things, it's more convenient, it makes people feel more confident about the product and its price and by using online shopping people avoid impulse buying. These factors altogether cause people can save more money in these difficult times.

One factor which affect saving trend is gender. According to the statistics women have had more serious reactions to financial crisis relative to men. They have decided to reduce their spending on different activities such as dining out, entertainment, online shopping and etc. On the other hand fewer men have made similar decisions. It can be inferred women are more cautious about events like economic turmoil.

Another factor affecting online consumer behavior and their saving trend is their age class. Each age class has its own preferential activities and try to cat back on other doings. Younger online shoppers try to delay making non essential retail purchases, control fixed monthly costs such as utilities and trimmed back on vacation plans. On the other hand older online shoppers try to cut down on the fuel consumption of their car and purchasing non essential retail items but they haven't decided to postpone their travels.

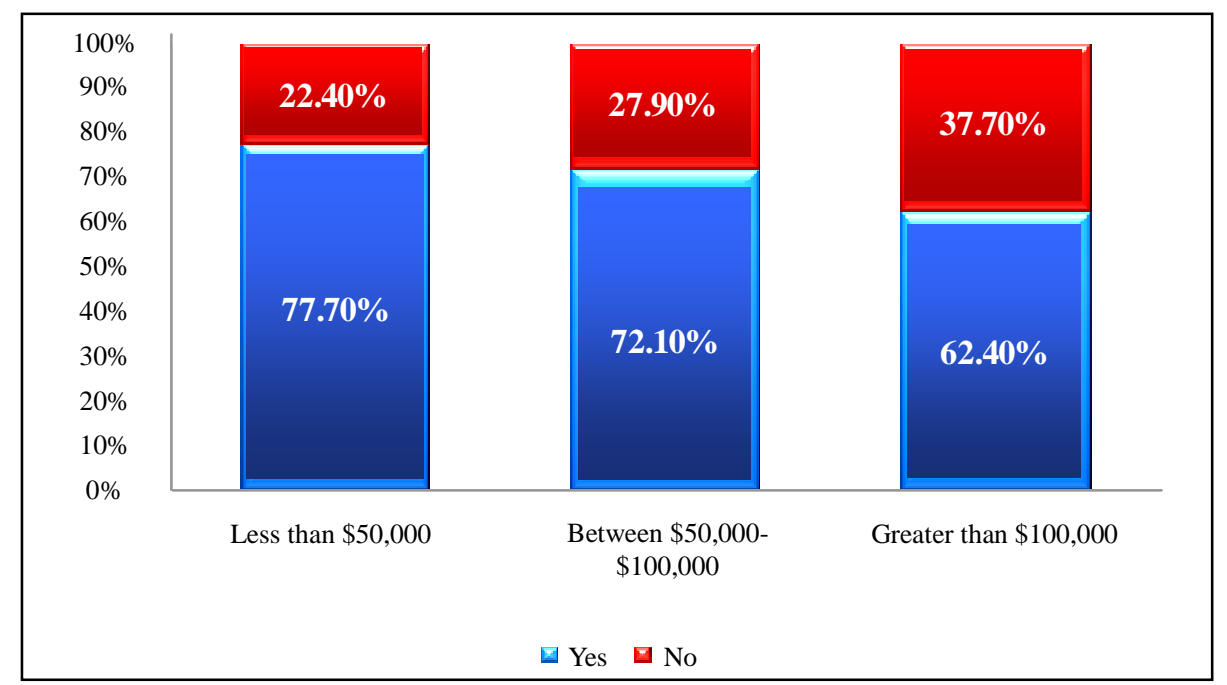

Figure 8. Are you planning to spend less money holiday season of 2008 than in past holiday season? [15] 
Finally the last factor which influences online buyers' behavior is income. It is obvious that more income results in more spending so those people, who have had high income, have been affected less the others by the crisis. On the other hand most of online buyers are wealthier than other buyers and so it's reasonable for them not to spend less. As can be seen in Figure 8 higher percentage of those people, who have less income, have decided to spend less.

\section{Conclusions}

According to the results of data analysis presented in the paper, financial crisis has impacted online retail industry in a negative way. Three factors play roles in this way: 1) lack of credit, 2) increasing saving rate, decreasing consumption rate and 3) decreasing CCI and CSI indices. It has caused online retail sales to decline but as have been seen its impact on the online retail sales is more moderate than offline retail sales. As described above e-commerce have inherent features which have resulted in attracting consumer to buy online in these difficult times. Moreover the crisis caused online buyers changed their buying habits. Several factors have affected this trend such as income, age class and gender. Online retailer should consider these affecting factors and use a proper marketing method for each group to make profit.

\section{REFERENCES}

[1] D. Baker, "The Housing Bubble and the Financial Crisis," Journal of Real-World Economics Review, 2008.

[2] CNBC.com, "Financial Crisis Has Inflationary and Deflationary Potential,” Consumer News and Business Channel, 2008, www.cnbc.com

[3] C. Miller, "Silicon Valley Barely Touched by Financial Crisis - So Far,” 2008, http//:www.nytimes.com

[4] P. Tam, B. Worthen and R. Guth, "Silicon Valley Finds it isn't Immune from Credit Crisis,” The Wall Street Jour- nal, 2008, http://online.wsj.com

[5] E-Commerce statistics, "Quarterly Retail e-Commerce Sales 1st Quarter 2008,” US Census Bureau News, May 2008.

[6] E-Commerce statistics, "Quarterly Retail e-Commerce Sales 2nd Quarter 2008,” US Census Bureau News, Aug 2008.

[7] E-Commerce statistics, "Quarterly Retail e-Commerce Sales 3rd Quarter 2008,” US Census Bureau News, Nov 2008.

[8] E-Commerce statistics, "Quarterly Retail e-Commerce Sales 4th Quarter 2008,” US Census Bureau News, Feb 2009.

[9] E-Commerce statistics, "Quarterly Retail e-Commerce Sales 1st Quarter 2009,” US Census Bureau News, May 2009.

[10] E-Commerce statistics, "Quarterly Retail e-Commerce Sales 2nd Quarter 2009,” US Census Bureau News, Aug 2009.

[11] P. Evans, V. Sehgal, C. Bugnaru and B. McGowan, "US Online Retail Forecast, 2008 to 2013,” Forrester Inc, March 2009.

[12] www.wikipedia.org

[13] BEA's Overview of the Economy. http//:www.bea.gov/ newsrelease/xls/glance.xls

[14] R. Curtin, "Economy Set to Improve, but Finances Expected to Remain Weak,” University of Michigan \& Reuters, Aug 2009.

[15] PriceGrabber Inc, "Holiday Online Shopping Forecast 2008,” PriceGrabber Inc., Los Angeles, 2008.

[16] S. Rodriguez, "Economic Climate Shifts Consumers Online,” PriceGrabber Inc., Los Angeles, March 2009.

[17] PriceGrabber Inc, "Economic Trends in Consumer SpenDing,” PriceGrabber Inc., Los Angeles, June 2009.

[18] A. J. Rousseau, "Consumers' Recession Reactions Vary by Generation,” Forrester Inc., Los Angeles, Dec 2008. 